Published January 2020

ENGLISH TEACHING AND LINGUISTICS

JOURNAL (ETLiJ)

ISSN 2716-0831 (online) | http://jurnal.umsu.ac.id/index.php/ETLiJ/index

\title{
The Effect of Task-Based Language Teaching On Students' Reading Comprehension of Tenth Grade of SMK Putra Anda Binjai Students In Academic 2018/2019
}

\author{
Juliantina \\ Pendidikan Bahasa Inggris \\ STKIP Budidaya Binjai \\ juliantinasebayang@gmail.com
}

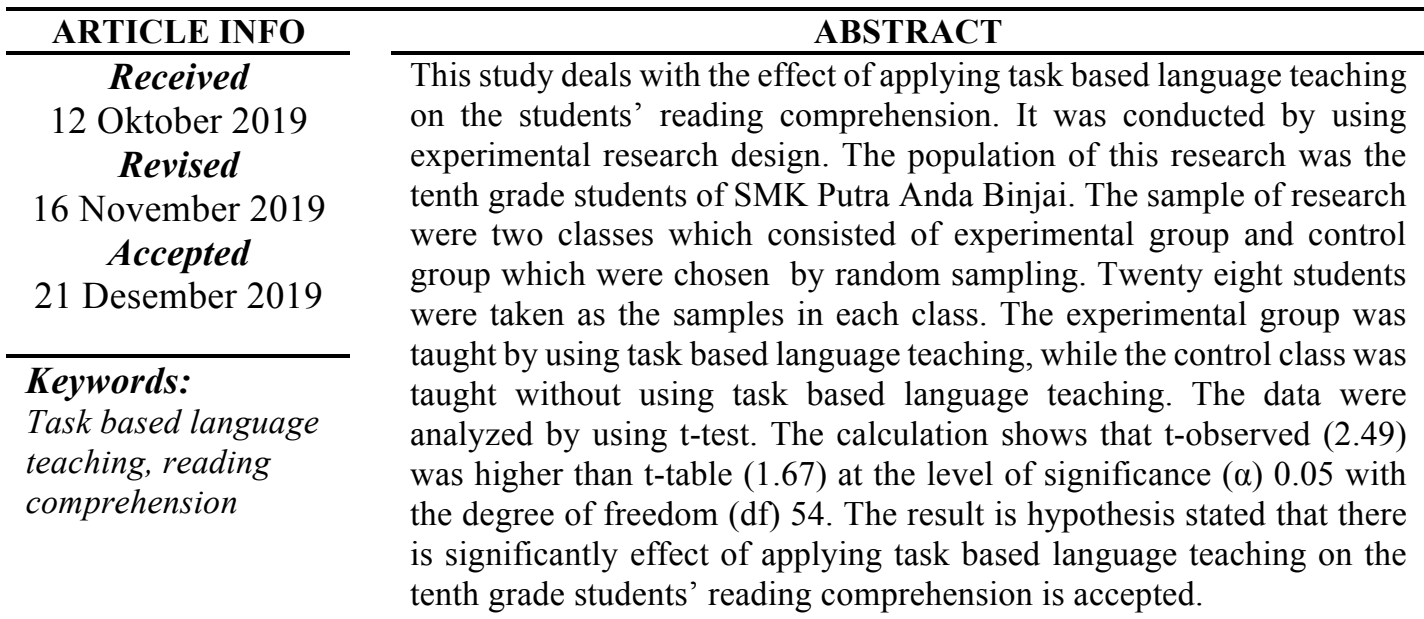

\section{Cara Sitasi:}

Juliantina. (2019). The Effect of Task-Based Language Teaching On Students' Reading Comprehension of Tenth Grade of SMK Putra Anda Binjai Students In Academic 2018/2019. English Teaching and Linguistics Journal, Vo. 1, No. 1, pp.28-33

\section{INTRODUCTION}

English an international language used in countries throughout the world, including Indonesia. In Indonesia, English was not only considered to be the first forigen language but it is thought as a copulsory subject from junior to vocational hight school. In Vocational High School, reading was one of the skills that have to be mastered by students learning English. Reading skill refers to the ability to understand writen text. It is advisable to develop this skill at early age of schooling. 
When some students comprehend or combine their understanding with prior knowledge, they are able to perform it. Reading is not just for the reading of words, but also for comprehending the meaning of written texts.Reading is a means of language acquisition, communication, and of sharing information and ideas. Reading is a multifaceted process involving word recognition, comprehension, fluency, and motivation. Reading is decoding and understanding written texts. Decoding requires translating the symbols of writing system into the spoken words which they represent. Understanding is determined by the purposes for reading, the context, the nature of the text, and the readers' strategies and knowledge. Reading comprehension is the ability to process text, understand its meaning, and to integrate it with what the reader already knows. Task Based Language Teaching (TBLT) is an approach to language learning.

TBLT refers to an approach based on the use of tasks as the core unit of planning and instruction in language teaching. Task Based Language Teaching is an approach which offer students opportunities to actively engage in communication in order to achieve a goal or complete a task. TBLT seeks to develop students' interlanguage through providing a task and then using language to solve it.

\section{REVIEW OF LITERATURE \\ 1. Reading}

Reading is a process of constructing meaning from written text. It is a complex skill requiring the coordination of interrelated sources of information. Reading is when someone looks into a written text and start to absorb the information from the written linguistic message. In other definition, reading is an act of looking at and understanding point. This is very true because reading entails the use of version to understand several words in a sentence and make them meaningful. Many or any people can read a text but hardly can understand what the writing was all about. This is because the reading was not providing any information to the reader. This happened when the reader merely read the text without understanding the content.

\section{Reading Comprehension}

The word "comprehend" refers to four aspects of reading competency that students are expected to learn: (1) main ideas from a variety of simple texts, (2) details and explicit information from a variety of simple texts, (3) the meaning of new words based on contextual clues, and (4) the communicative purpose and rhetorical structure of such texts. Thus it is clear that students are expected to understand and master the reading of various types of texts. Jeniffer Serravallo stated that comprehension is at the heart of what is means to really read by thingking and understanding and getting at the meaning behind a text.

In according to Kruidenier elaborated that comprehension is an active process and the reader must interact and be engaged with text for it to work well. It $\mathrm{s}$ also a strategic process which can be taught.

Furthermore, Bonnie. Armbruster also defined tha comprehension is the reason for reading. If readers can read the word but not understaind what they are 
read the word but do not understaind what they are reading, they are not really reading.

There are three reading technique that are commonly known:

a. Skimming

Skimming give readers the advantage of being able to predict the purpose of the passage, the main topic or message and possibly some of the developing or supporting ideas.

b. Scanning

The purpose of scanning is to extract certain specific information without reading through the whole text. For academic English, scanning is absolutely.

c. Semantic Mapping or Clustering

The strategy of semantic mapping, or grouping ideas into meaningful clusters, helps the readers to provide some order to the chaos.

\section{Task-based Language Teaching}

Task-based language teaching (TBLT), also we know as task-based instruction (TBI), focuses on the use of autentic language and on asking students to do meaningful tasks using the target language. TBLT was first developed by N. Prabu in Bangladore, Southern India. Prbu believed thier minds are focused on task, rather than on the language they are using.

According to Rod Ellis, a task has four meaning characteristics: a) A task invloves a primary focus on (pragmatic); b) A task has some kind of 'gap' (Prabu identified the three main type as information gap, reasoning gap, and opinion gap); c) The participants choose the linguistic resources needede to complete the task; d) A task has a clearly defined, non-linguistic outcome.

\section{RESEARCH METHODOLOGY}

This research would be conducted of the 2018/2019 tenth year students of SMKPutra Anda Binjai that locatedat JL. W.R Mongonsidi no.22, kel.Satria kec. Binjai kota, kab. kota Binjai. The writer chosen SMKPutra Anda Binjai as the research location because there had been no same research conducted in this school before and from this location, the writer could be easily to get the data needed in this research because easy in reach.

This study was conducted in experimental design. It meant that the writer attempted to describe a casual relationship between independent and dependent variable. This design was applied to investigate the effect of taskbased language teaching on students' reading comprehension. "Experimental research involves a study of the effect of the systemic manipulation of one variable on another variable". Therefore, this study also dealt with two groups, they were: experimental and control group. The pre-test and post-test were administered to both groups.

The population in this study is all tenth grade of SMK Putra Anda Binjai Students in academic year 2018/2019. There are some majors in this school such as TKJ, TAV, Perkantoran, Akuntansi, Tata boga, Busana Butik, Pemasaran, TSM, and Body repair and the tenth grade students in academic year 2017/2018 aggregate 355 students. 
Instrument of research using multiple-choice testto measure something that we observe in other to obtain the data and answer the research. In the test there are 10 questions of multiple choices, the score in each question is 10 for correct answer. the writer give the same test for experimental and control class, but the test for experimental class. Pre-test was administered to the both experimental and control group. Pre-test was conducted to find out and to describe if the two groups of the students were relatively homogenous in reading comprehension. Having done the treatment, post-test was given to the students. Post-test was administered to know the differences score both of experimental and control group. The data were from experimental group and control group. "The data are analyzed by using "t-test for independent sample" developed by arikunto to know the effect or result of the research".

\section{THE DATA AND DATA ANALYSIS}

This research was conducted by using experimental research. There were two randomized groups used namely experimental group and control group. The population of this research was the tenth grade students of SMK Putra Anda Binjai. By using random sampling, the sample were taken namely class $\mathrm{X} \mathrm{TKJ}^{1}$ for experimental group and class $\mathrm{X} \mathrm{TKJ} \mathrm{T}^{2}$ for the control group.

To obtain the data, reading test was given to the students, the data were obtained from the students' reading score in the pre-test and post-test from the two groups. The data of pre-test in experimental group were: the highest score was 80, the lowest score was 50. While the data pre-test in control group were: the highest was 80 , the lowest score was 50 . Based on the data, it can be concluding that the students' score in experimental group was higher than the students' score in control group.

From the data which had obtained in the post-test of experimental group were: the highest score was 90, the lowest was 60 , while the data of posttest in control group were: the highest score was 80 , the lowest score was 50 . Based on the data. It can be concluded that the students' score in experimental group was higher than the students' score in control group.

To find out the whether the applying of Task Based Language Teaching had effect on the SMK students' reading comprehension, the result of the test was calculated by using t-test formula.

The calculation shows that:

$$
\begin{aligned}
& \mathrm{M}_{x}=8,57 \\
& \mathrm{M}_{y}=6,25 \\
& \mathrm{dx}^{2}=342.75 \\
& \mathrm{dy}^{2}=331.18 \\
& \mathrm{~N}_{x}=28 \\
& \mathrm{~N}_{y}=28
\end{aligned}
$$

The data showed from tables above, than were calculated and analyzed by using t- test formula:

$$
\mathrm{t}=\frac{\mathrm{M}_{\chi}-\mathrm{M}_{\gamma}}{\sqrt{\left[\frac{d x^{2}+d y^{2}}{N_{x}+N_{y}-2}\right]\left[\frac{1}{N_{x}}+\frac{1}{N_{y}}\right]}}
$$




$$
\begin{aligned}
& t=\frac{8,57-5.53}{\sqrt{\left[\frac{342,75+331,18}{28+28-2}\right]\left[\frac{1}{28}+\frac{1}{28}\right]}} \\
& t=\frac{2,32}{\sqrt{\left[\frac{67,93}{54}\right][0,07]}} \\
& t=\frac{2,5}{\sqrt{12,48 \times 0,07}} \\
& t=\frac{2,5}{\sqrt{0,87}} \\
& t=\frac{2,5}{0,93} \\
& t=2,49
\end{aligned}
$$

After calculating the data above, the value of t-table for the df (degree of freedom $)$ of $54\left(\mathrm{n}_{1}+\mathrm{n}_{2}-2\right.$ or $\left.28+28-2\right)$ at level significance $(\alpha) 0,05$ is 1,673 .The result of computing t-.test shows that the value of t-test is higher than the value of $\mathrm{t}$-table as follows.

Based on the calculation of the data, the critical value or t-observed $\left(\mathrm{t}_{0}\right)$ is higher than the value of $t$-table $\left(t_{0}=2,49>t_{t}=1,673\right)$. It means that the alternative hypothesis is accepted.

\section{CONCLUSION AND SUGGESTION}

\section{a. Conclusion}

From the result of the data analysis in the previous chapter, the writer compose a conclusion that in testing the hypothesis, the value of $t$-observed $\left(\mathrm{t}_{0}\right)$ is higher than the value of $t$-table, $t_{0}=2,19>t_{t}=1,673$. Therefore, the hypothesis proposed by the writer is accepted. In other words, using Task Based Language Teaching affects reading comprehension of the tenth grade students of SMK Putra Anda Binjai.

\section{b. Suggestion}

From the conclusion stated above, the writer would like to offer some suggestions with the result of this study. The suggestions are:

1. The students should do more exercises of English reading test in order to increase their reading skill.

2. The students should be more active and cooperative when they learn when they learn about English lesson by using Task Based Language Teaching because it will help them become more interesting in English learning.

3. The teacher should motivate the students to read and practice more.

4. other researcher should be read the findings of this study as one of The consideretions to making decision for the policy of the teaching learning process.

\section{REFERENCES}

Cline, F, Johnstone, C, \& King, T, Focus Group Reaction to Three Definition of Reading (as Originally Developed in Support NARAP Goal 1). Minneapolis, M.N : National Accessible Reading Assessment Project .(2006).

Valencia, Spain. Reading comprehension. Retrieved from http://www.eric.ed.gov/contentdelivery/servlet/ERICServlet?accno=ED50 4676; Jump up ^ Iwai, Y. (2008). 
Prabu, cited in littlewood. 2014.

Stanley, S. An Analysis of Rx Discovery ReadingRTM for Elementary Students Below Average in Reading (The United States of American : ProQuest Information and Learning Company, 2007).

Essays, UK. Definition of Reading. Retrieved from https://www.ukessays.com/essays/languages/definitions-ofreading.php?vref=1 accessed on July 20, 2019.

Irfan, 'The effect of task based language teaching on students' reading comprehension.". English education journal (eej).(2017)8(1), 113-126, Retieved from http://www.jurnal.unsyiah.ac.id/EEJ/article/download/6132/5036. July 20, 2019.

Serraval, Jenifer, Teaching Reading in Small Group (USA : Heinemann, 2010.

Kruidenier, Jhon, Research-Based Principle for Adult Basic Education Reading Instrucion (USA : The National Institute for Literacy, 2002).

Bonnie B, Armbruster, Put Reading First : the Research BuildingBlock for Teaching (third Edition, USA : National Institude for Literacy) 2000.

Ellis, Rod . Task-based Language Learning and Teaching (Oxfort, New York: Oxford Applied Linguistic, 2003).

D Ary, Introduction to Research in Education (Singapore: Wardswirth, 2002).

S Arikunto, Prosedure Penelitian: Suatu Pendekatan Praktek (Jakarta PT Rineka Cipta, 2006). 